\title{
Investigating Antibacterial Effects of Latrodectus Dahli Crude Venom on Escherichia coli, Staphylococcus aureus and Bacillus subtilis
}

\author{
Mohsen Mousavi (MSc) \\ Department of Biology, Faculty of \\ Basic Science, Imam Hossein \\ University, Tehran, Iran \\ Behrooz Johari (PhD) \\ Department of Medical Biotechnology, \\ School of Medicine, Zanjan University \\ of Medical Sciences, Zanjan, Iran \\ Jamil Zargan (PhD) \\ Department of Biology, Faculty of \\ Basic Science, Imam Hossein \\ University, Tehran, Iran \\ Ashkan Haji Noor Mohammadi \\ (MSc) \\ Department of Biology, Faculty of \\ Basic Science, Imam Hossein \\ University, Tehran, Iran \\ Hamid Reza Goudarzi (PhD) \\ Department of Venomous Animals and \\ Antivenin Production, Razi Vaccine \\ and Serum Research Institute, Karaj, \\ Iran \\ Saeed Dezianian (MSc) \\ Department of Biology, Faculty of \\ Basic Science, Imam Hossein \\ University, Tehran, Iran \\ Hani Keshavarz Alikhani (PhD) \\ Department of Biology, Faculty of \\ Basic Sciences, Razi University, \\ Kermanshah, Iran \\ Corresponding author: Jamil Zargan \\ Email: jzargan@ihu.ac.ir \\ Tel: $+98-2173820000$ \\ Address: Department of Biology, \\ Faculty of Basic Sciences, Imam \\ Hossein University, Tehran, Iran \\ Received: 03 Mar 2018 \\ Revised: 02 Feb 2018 \\ Accepted: 28 Feb 2018

\section{(c) (i) (8)} \\ This work is licensed under a Creative \\ Commons Attribution 4.0 License.
}

\begin{abstract}
Background and Objectives: Nowadays, infections with antibiotic-resistant bacteria are among the most important causes of mortality worldwide. This has attracted the attention of researchers to seek suitable alternatives for antibiotics. The venom of many toxic species such as arthropods has antibacterial properties. In this study, we investigated antibacterial effects of crude venom of Latrodectus dahli on Escherichia coli, Staphylococcus aureus, and Bacillus subtilis.

Methods: Lyophilized crude venom of $L$. dahli was dissolved in $50 \mathrm{mII}$ Tris-HCl buffer. Protein concentration was determined by the Bradford assay. Then, the bacteria were exposed to different concentrations $(31.25-250 \mathrm{ng} / \mathrm{mL})$ of the crude venom. Inhibitory activity of the venom against the bacteria was determined by MTT assay and determining minimum inhibitory concentration (MIC).

Results: Results of the MTT assay showed that the crude venom significantly inhibited the growth of E. coli (31.25 and $62.5 \mathrm{ng} / \mathrm{mL}$ ), S. aureus (at $250 \mathrm{ng} / \mathrm{mL}$ ) and $B$. subtilis (at 125 and $250 \mathrm{ng} / \mathrm{mL}$ ). In the VIC experiment, the crude venom significantly inhibited the growth of E. coli (at concentrations of 31.25 and $62.5 \mathrm{ng} / \mathrm{mL}$ ), S. aureus (at concentrations of $31.25-250 \mathrm{ng} / \mathrm{mL}$ ) and B. subtilis (at concentrations of $31.25-250 \mathrm{ng} / \mathrm{mL}$ ).
\end{abstract}

Conclusion: The crude venom of $L$. dahli and its components showed relatively strong antibacterial effects. resistance.

This paper should be cited as: Mousavi M, Johari B, Zargan J, Haji Noor Mohammadi A, Goudarzi HR, Dezianian S, Keshavarz Alikhani H[Investigating Antibacterial Effects of Latrodectus Dahli Crude Venom on Escherichia coli, Staphylococcus aureus and Bacillus subtilis]. mljgoums. 2019; 13(3):14-19 


\section{INTRODUCTION}

Recently, researchers have focused on antimicrobial peptides (AMPs) to combat antibiotic resistance $(1,2)$. These peptides contain deformed amino acids that are not found in polypeptides made by ribosomes. Research has shown that these compounds have great medicinal potential. Selective toxicity is an essential characteristic of an antimicrobial agent. Ideally, such compounds have affinity for one or more microbial determinants that are easily accessible, common to a broad spectrum of microbes and relatively immutable. Nature seems to develop a class of molecules that meet these constraints in the evolution of AMPs, which initially target microbial cells, and thus fulfill the criteria mentioned above for identifying molecular determinants of pathogens. AMPs have amphipathic features that mirror phospholipids, thus allowing them to interact with and exploit vulnerabilities inherent in essential microbial structures such as cell membranes (3). Until now, the antibacterial activity of more than 1000 peptides from different eukaryotic and prokaryotic sources have been investigated to find a suitable antimicrobial alternative for antibiotics $(4,5)$.

It has been demonstrated that venom of snakes, scorpions and spiders has strong antibacterial effects (6). Some studies have also shown that AMPs have anticancer effects $(7,8)$. Peptides from arthropods are cationic and amphiphilic and do not contain cysteine residues (9). Spiders are members of arthropods and have more than 60 families and 35000 species. They live in nearly every habitat on earth (10). Latrodectus spider, also known as the black widow, is a member of the Theridiidae family (11). The venom of this spider contains $\alpha$-latrotoxin, a $130 \mathrm{kDa}$ mammalian neurotoxin that has been used for studying exocytosis in cells (12). In this study, we investigate antibacterial effects of the venom of black widow spider on Escherichia coli, Staphylococcus aureus, and Bacillus subtilis.

\section{MATERIALS AND METHODS}

3-(4,5-Dimethyl-2-thiazolyl-2)-2,5-

diphenyl-tetrazolium bromide (MTT) powder, flat bottom 96-well plates and dimethyl sulfoxide (DMSO) were purchased from Sigma-Aldrich, USA. Tris-HCL and crude venom of the black widow spider were purchased from Merck (Germany) and Razi Institute (Iran), respectively. Lyophilized venom was dissolved in $250 \mu \mathrm{L}$ of Tris- $\mathrm{HCl}$ buffer $(50 \mathrm{mM})$, incubated at $4^{\circ} \mathrm{C}$ and then kept in a freezer at $-20^{\circ} \mathrm{C}$.

The Bradford assay was used for determining protein concentrations. Bovine serum albumin (BSA) was used for plotting the standard curve and microplate spectrophotometer (Epoch, Biotek) was used for measuring the absorbance of the samples at $595 \mathrm{~nm}$.

E. coli (ATCC 25922), S. aureus (ATCC 25923) and B. subtilis (ATCC 6633) were purchased from the Persian Type Culture Collection (PTCC).

In brief, the bacteria were cultured in Mueller Hinton broth media inside of a 96-well plate until reaching turbidity of $0.5 \mathrm{McF}$ arland (Qlab). Minimum inhibitory concentration (MIC) was calculated as the lowest concentration of venom that inhibited bacterial growth (13).

The bacteria were exposed to different concentrations of the crude venom (31.25-250 $\mathrm{ng} / \mathrm{mL})$. Tetracycline $(50 \mu \mathrm{g} / \mathrm{mL})$ and bacterial suspension were used as positive and negative controls, respectively. In addition, Mueller Hinton broth was used as a blank. The final volume for each well of 96 plate was set as $100 \mu \mathrm{L}$. The assay was repeated three times for each concentration.

After 15 to 18 hours of incubation at the defined condition, cell density was measured at $605 \mathrm{~nm}$ (14). MIC was calculated using the following equation: $\quad$ MIC $=(1-$
$\left.\frac{\text { OD sample-OD blank }}{\text { OD negative control- OD blank }}\right) \times 100$. After 15 to 18 hours, $5 \mu \mathrm{L}$ of MTT dye ( 5 $\mathrm{mg} / \mathrm{mL}$ ) were added to all wells and the plate was incubated for one hour in dark at $37{ }^{\circ} \mathrm{C}$. Then, $100 \mu \mathrm{L}$ of DMSO was added to each well and the plate was incubated for two more hours in dark. Absorbance was read at $595 \mathrm{~nm}$ (15). All experiments were carried out in triplicate. Cell viability was calculated using the following equation: viability $=$ $\frac{O D \text { sample-OD blank }}{\text { OD negative control }- \text { OD blank }} \times 100$.

Results were reported as mean \pm standard deviation (SD) and data were analyzed in the GraphPad Prism 6.1 software (GraphPad Software Inc., USA) using ANOVA and the Tukey test. A p-value of less than 0.05 was considered statistically significant. 


\section{RESULTS}

The results of MIC assay indicated that 31.25 and $62.5 \mathrm{ng} / \mathrm{mL}$ of the crude venom had significant inhibitory effects on the growth of E. coli cells. However, the inhibitory effect of the control antibiotic was much stronger than that of the crude venom. The MIC values of the crude venom were $9.3 \pm 4.61,9 \pm 3.60$, $5.7 \pm 4.04$ and $3.7 \pm 3.05$ percent against $E$. coli at the concentrations of $31.25,62.5,125$ and $250 \mathrm{ng} / \mathrm{mL}$, respectively. The MIC analysis of the antibiotic for these cells showed that 99.16 \pm 0.40 percent of the cells were inhibited when using $50 \mu \mathrm{g} / \mathrm{mL}$ of the venom (Figure 1A).

Results of the MTT assay showed that 31.25 and $62.5 \mathrm{ng} / \mathrm{mL}$ of crude venom have significant inhibitory effects on the growth of E. coli compared with the control. However, the antibiotic showed stronger antibacterial activity compared to the crude venom. The viability of $E$. coli was $85.7 \pm 5.09,90.3 \pm 1.15$, $93.7 \pm 0.87$ and $98 \pm 3.46$ percent when using $31.25,62.5,125$, and $250 \mathrm{ng} / \mathrm{mL}$ of crude venom, respectively. The viability of $E$. coli was $4.64 \pm 3.67$ percent when using $50 \mu \mathrm{g} / \mathrm{mL}$ of the antibiotic (Figure 1B).

Concentrations of $31.25-250 \mathrm{ng} / \mathrm{mL}$ of crude venom had significant inhibitory effects against $S$. aureus. MIC of the crude venom was $5 \pm 1,3.7 \pm 2.08,3 \pm 1$, and 2 percent at the concentrations of $31.25,62.5,125$, and 250 $\mathrm{ng} / \mathrm{mL}$, respectively. However, the inhibitory effect of the antibiotic was much stronger than the crude venom against $S$. aureus (Figure 2A). Results from MTT showed that 250 $\mathrm{ng} / \mathrm{mL}$ of the crude venom had significant inhibitory effect on the growth of S. aureus. However, the viability of $S$. aureus treated with tetracycline $(50 \mu \mathrm{g} / \mathrm{mL})$ was much lower $(16.7 \pm 5.03$ percent $)$ than those treated with venom (Figure 2B).

The crude venom at concentrations of 31.25$250 \mathrm{ng} / \mathrm{mL}$ had significant inhibitory effect on the growth of $B$. subtilis. MIC of the crude venom was $7.7 \pm 0.87,7.7 \pm 1.32,7.9 \pm 2.08$ and $7.8 \pm 4$ percent at the concentrations of 31.25 , $62.5,125$ and $250 \mathrm{ng} / \mathrm{mL}$, respectively. Based on the results, $50 \mu \mathrm{g} / \mathrm{mL}$ of antibiotic showed stronger inhibitory activity than the mentioned concentration of crude venom (Figure 3A).

In the MTT assay, concentrations of 125 and $250 \mathrm{ng} / \mathrm{mL}$ of crude venom had significant inhibitory effects on the growth of B. subtilis. $B$. subtilis viability was $97 \pm 2,98 \pm 1.73$, $90.3 \pm 3.02$ and $91 \pm 2$ percent at concentrations of $31.25,62.5,125$ and $250 \mathrm{ng} / \mathrm{mL}$, respectively. However, tetracycline showed higher inhibitory effect against this bacterium compared to the venom (Figure 3B).

Figure 1-(A) Inhibitory effects of different concentrations of crude venom against $E$. coli in the MIC assay. (B) Viability of $E$. coli after exposure to $31.25-250 \mathrm{ng} / \mathrm{mL}$ of crude venom in the MTT assay $\left(1.5 \times 10^{8}\right.$ cells $/$ well $)$. Tetracycline $(50 \mu \mathrm{g} / \mathrm{mL})$ and $\mathrm{medium}$ without crude venom were used as the positive and negative control, respectively (ns: non-significant, ${ }^{*}: p<0.05, * *: p<0.01, * * *$ : $p<0.001, * * * *: p<0.0001)$

A

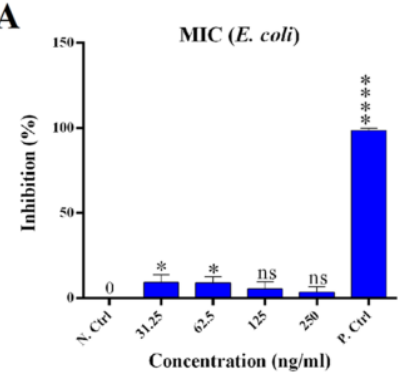

B

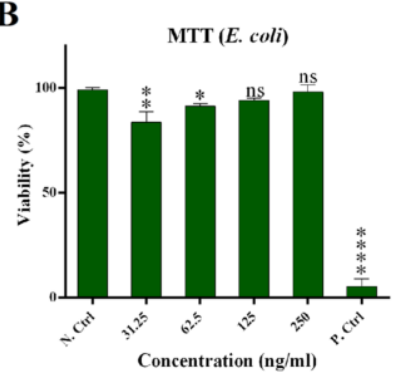

Figure 2- (A) Inhibitory effects of different concentrations of crude venom against $S$. aureus in the MIC assay. (B) Viability of $S$. aureus after exposure to $31.25-250 \mathrm{ng} / \mathrm{mL}$ of crude venom in the MTT assay $\left(1.5 \times 10^{8}\right.$ cells $/$ well $)$. Tetracycline $(50 \mu \mathrm{g} / \mathrm{mL})$ and $\mathrm{medium}$ without crude venom were used as the positive and negative control, respectively (ns: non-significant, $*$ : $p<0.05$, **: $p<0.01, * * *$ : $p<0.001, * * * *: p<0.0001)$.
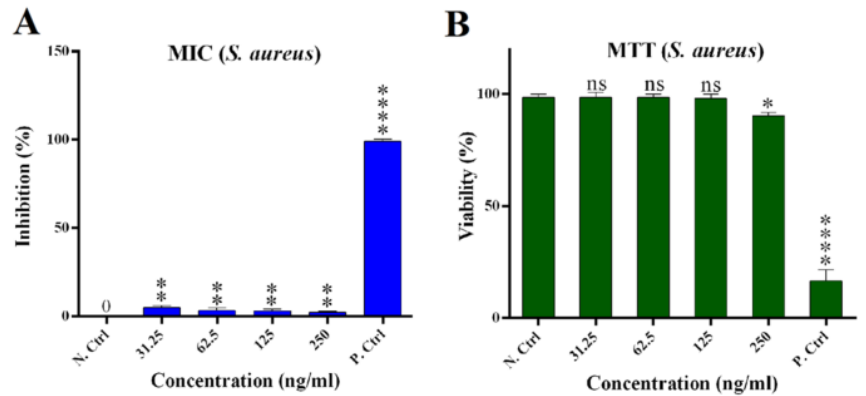

$p<0.0001)$

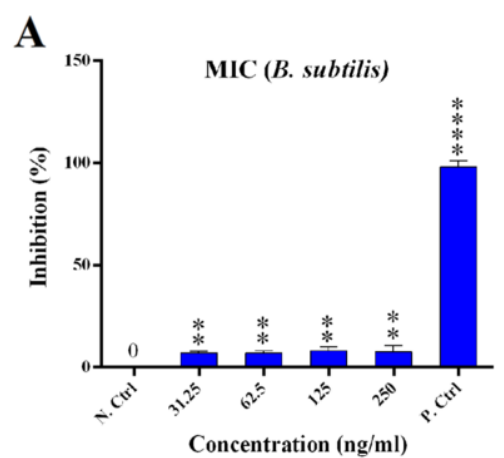

\section{DISCUSSION}

Since the discovery of penicillin in 1940, various antibiotics have been proposed for the treatment of bacterial diseases and control of bacterial epidemics (16). The emergence of antibiotic-resistant bacteria along with the side effects of antibiotics, namely allergic hypersensitivity and immunosuppression $(17,18)$ encouraged researchers to seek for new generations of antibiotics or alternative antimicrobials (1921). Recently, isolation of antibacterial molecules from animals, such as AMPs has been considered for the treatment of diseases. Venoms of different species such as snakes, spiders, insects, centipede and amphibians are rich sources of biologically active and therapeutic compounds including AMPs $(4,6$, 22-24).

The innate immune system of arthropods has evolved a complex arrangement of constitutive and inducible AMPs that immediately destroy a large variety of pathogens. In this complex system, several enzymes, low-molecular-mass compounds, neurotoxins, antimicrobial and cytolytic peptides interact together, resulting in extremely rapid immobilization and/or killing of prey or aggressors (25). Many studies have shown that the venom of snakes, scorpions and spiders have antibacterial effects (6). As the largest venomous animals with more than 50000 species (26), spiders and their venom have been long used in traditional medicine for treatment of various diseases (27). In this study, we investigated the inhibitory effects of crude venom from black widow spider ( $L$. dahli) against a number of bacteria using the

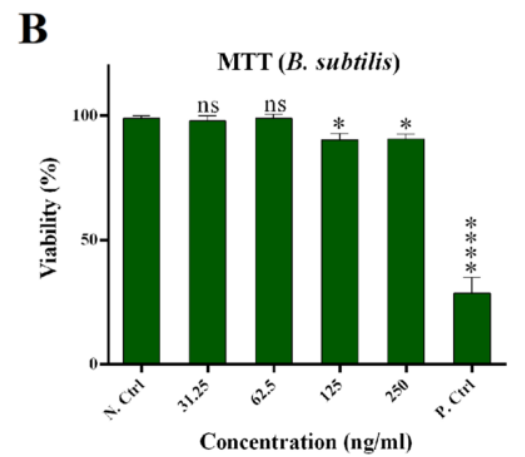

MTT assay and MIC determination. Disc diffusion and well diffusion methods had low reproducibility and were not suitable for this study. Since the venom was water insoluble, paper discs (as a filter and block) were used in the disc diffusion assay for evaluating the antibacterial activity of the crude venom and its components during culture (28-31).

Some studies have suggested that the antimicrobial effect of venom is promoted by the increased permeability of the bacterial cell membrane induced by antimicrobial proteins present in spider venom (32). The results indicated that $31.25,62.5,125$ and $250 \mathrm{ng} / \mathrm{mL}$ of the crude venom had significant antibacterial effects against all tested bacteria. A study performed by Amirmozafari et al. in 2015 revealed that concentrations of 100, 250 and $500 \mu \mathrm{g} / \mathrm{mL}$ of Tarantula Cubensis venom (Theranekron) have no antibacterial effect on E. coli strain $\mathrm{K}-12, \quad S$. aureus and Pseudomonas aeruginosa (33).

A study carried out by Lei et al. in 2015 showed that protein components purified from the Latrodectus tredecimguttatus egg as Latroeggtoxin-IV $(1.8 \mu \mathrm{g} / \mathrm{disc})$ has higher antibacterial activity against $S$. aureus compared to B. subtilis and E. coli (34). In 2008, Benli and Yigit reported that the venom of Agelena labyrinthica has more inhibitory effects on B. subtilis compared to the $S$. aureus and E. coli (19). In our study, the results of MTT assay showed that the crude venom could significantly reduce the viability of E. coli (at 31.25 and $62.5 \mathrm{ng} / \mathrm{mL}$ ), S. aureus 
(at $250 \mathrm{ng} / \mathrm{mL}$ ) and B. subtilis (at 125 and 250 $\mathrm{ng} / \mathrm{mL}$ ). In the MIC experiment, the crude venom significantly inhibited the growth of $E$. coli (at 31.25 and $62.5 \mathrm{ng} / \mathrm{mL}$ ), S. aureus (at $31.25-250 \mathrm{ng} / \mathrm{mL}$ ) and B. subtilis (at 31.25 $250 \mathrm{ng} / \mathrm{mL}$ ). Altogether, these results indicated that the crude venom significantly inhibited the growth of $E$. coli at low concentrations and $S$. aureus and $B$. subtilis at high concentrations.

\section{CONCLUSION}

The crude venom of black widow spider, $L$. dahli, has relatively strong antibacterial effects. This suggests that the crude venom of this spider may be a suitable

\section{REFERENCES}

1. Kobbi S, Nedjar N, Chihib N, Balti R, Chevalier M, Silvain A, et al. Synthesis and antibacterial activity of new peptides from Alfalfa RuBisCO protein hydrolysates and mode of action via a membrane damage mechanism against Listeria innocua. Microbial pathogenesis. 2018;115:41-9. doi: 10.1016/j.micpath.2017.12.009.

2. Nascimento Canhas I, Dias Heneine LG, Fraga T, Sampaio de Assis DC, Borges MH, Chartone-Souza E, et al. Antibacterial activity of different types of snake venom from the Viperidae family against Staphylococcus aureus. Acta Scientiarum Biological Sciences. 2017; 39(3): 309-319.

3. Yeaman MR, Yount NY. Mechanisms of antimicrobial peptide action and resistance. Pharmacological reviews. 2003; 55(1): 27-55.

4. Abtahi B, Mosafer Khorjestan S, Ghezellou P, Aliahmadi A, Ranaei Siadat SO, Kazemi SM, et al. Effects of Iranian Snakes Venom True Sea and Terrestrial Snakes on Some Bacterial Cultures. Journal of the Persian Gulf. 2014; 5(18): 27-36.

5. Starr CG, Wimley WC. Antimicrobial peptides are degraded by the cytosolic proteases of human erythrocytes. Biochim Biophys Acta Biomembr. 2017; 1859(12): 2319-2326. doi: 10.1016/j.bbamem.2017.09.008.

6. Primon-Barros M, José Macedo A. Animal Venom Peptides: Potential for New Antimicrobial Agents. Current topics in medicinal chemistry. 2017; 17(10): 1119-56. doi: 10.2174/1568026616666160930151242.

7. Deslouches B, Di YP. Antimicrobial peptides with selective antitumor mechanisms: prospect for anticancer applications. Oncotarget. 2017; 8(28): 46635.

8. Troeira Henriques Sn, Lawrence N, Chaousis S, Ravipati AS, Cheneval O, Benfield AH, et al. Redesigned spider peptide with improved antimicrobial and anticancer properties. ACS Chemical Biology. 2017; 12(9): 2324-34. DOI: 10.1021/acschembio.7b00459.

9. Kuhn-Nentwig L. Antimicrobial and cytolytic peptides of venomous arthropods. Cellular and Molecular Life Sciences CMLS. 2003; 60(12): 2651-68. source of antibacterial.

\section{ACKNOWLEDGEMENTS}

This work was supported by the Imam Hossein Comprehensive University. The authors are grateful to the Biology Research Center of the University for their support and the Razi Vaccine \& Serum Research Institute for providing the crude venom.

Dr. Abbas Hajizade is also sincerely acknowledged for language editing of the manuscript.

\section{CONFLICT OF INTEREST}

The authors declare that there is no conflict of interest.

10. Zamani A, Mirshamsi O, Savoji A, Shahi M. Contribution to the distribution of spiders with significant medical importance (Araneae: Loxosceles and Latrodectus) in Iran, with a new record for the country. Iranian Journal of Animal Biosystematics. 2014 Aug 13; 10 (1): 57-66.

11. Abolfazl A, Ahmad TM, Hadi R. Venom and envenomation of Iranian black widow spider, Latrodectus. Journal of Experimental Zoology, India. 2013; 16(2): 541-3.

12. Ushkaryov YA, Rohou A, Sugita S. $\alpha$-Latrotoxin and its receptors. Handb Exp Pharmacol. 2008; 184: 171206.

13. Andrews JM. Determination of minimum inhibitory concentrations. Journal of antimicrobial Chemotherapy. 2001; 48(suppl 1): 5-16.

14. Shebl R, Mohamed A, Ali AE, Amin M. Antimicrobial Profile of Selected Snake Venoms and Their Associated Enzymatic Activities. 2012; 2(4): 251263.

15. Wang H, Cheng H, Wang F, Wei D, Wang X. An improved 3-(4, 5-dimethylthiazol-2-yl)-2, 5-diphenyl tetrazolium bromide (MTT) reduction assay for evaluating the viability of Escherichia coli cells. J Microbiol Methods. 2010; 82(3): 330-3. doi: 10.1016/j.mimet.2010.06.014.

16. Garcia F, Villegas E, Espino-Solis GP, Rodriguez A, Paniagua-Solis JF, Sandoval-Lopez G, et al. Antimicrobial peptides from arachnid venoms and their microbicidal activity in the presence of commercial antibiotics. J Antibiot (Tokyo). 2013; 66(1): 3-10. doi: 10.1038/ja.2012.87.

17. Roose-Amsaleg C, Laverman AM. Do antibiotics have environmental side-effects? Impact of synthetic antibiotics on biogeochemical processes. Environ Sci Pollut Res Int. 2016; 23(5): 4000-12. doi: 10.1007/s11356-015-4943-3 
18. Langdon A, Crook N, Dantas G. The effects of antibiotics on the microbiome throughout development and alternative approaches for therapeutic modulation. Genome Med. 2016; 8(1): 39. doi: 10.1186/s13073-0160294-z.

19. Benli M, Yigit N. Antibacterial activity of venom from funnel web spider Agelena labyrinthica (Araneae: Agelenidae). Journal of Venomous Animals and Toxins including Tropical Diseases. 2008; 14(4): 641-50.

20. Walsh CT, Wencewicz TA. Prospects for new antibiotics: a molecule-centered perspective. The Journal of antibiotics. 2014; 67(1): 7-22.

21. Butler MS, Blaskovich MA, Cooper MA. Antibiotics in the clinical pipeline at the end of 2015. Antibiotics in the clinical pipeline at the end of 2015. J Antibiot (Tokyo). 2017; 70(1): 3-24. doi: 10.1038/ja.2016.72.

22. Harrison PL, Abdel-Rahman MA, Miller K, Strong PN. Antimicrobial peptides from scorpion venoms. Toxicon. 2014; 88: 115-37. doi: 10.1016/j.toxicon.2014.06.006.

23. da Mata ÉCG, Mourão CBF, Rangel M, Schwartz EF. Antiviral activity of animal venom peptides and related compounds. J Venom Anim Toxins Incl Trop Dis. 2017; 23(1): 3. doi: 10.1186/s40409-016-0089-0.

24. Abreu TF, Sumitomo BN, Nishiyama MY, Oliveira UC, Souza GH, Kitano ES, et al. Peptidomics of Acanthoscurria gomesiana spider venom reveals new toxins with potential antimicrobial activity. J Proteomics. 2017; 151: 232-242. doi: 10.1016/j.jprot.2016.07.012.

25. Kuhn-Nentwig L. Antimicrobial and cytolytic peptides of venomous arthropods. Cell Mol Life Sci. 2003; 60(12): 2651-68.

26. Samy RP, Stiles BG, Franco OL, Sethi G, Lim LH. Animal venoms as antimicrobial agents. Biochemical pharmacology. 2017; 134: 127-38. doi: 10.1016/j.bcp.2017.03.005.

27. Liu Z, Zhao Y, Li J, Xu S, Liu C, Zhu Y, Liang S. The venom of the spider Macrothele raveni induces apoptosis in the myelogenous leukemia K562 cell line. Leuk Res. 2012; 36(8): 1063-6. doi: 10.1016/j.leukres.2012.02.025.
28. Al-Asmari AK, Alamri MA, Almasoudi AS, Abbasmanthiri R, Mahfoud M. Evaluation of the in vitro antimicrobial activity of selected Saudi scorpion venoms tested against multidrug-resistant micro-organisms. J Glob Antimicrob Resist. 2017; 10: 14-18. doi: 10.1016/j.jgar.2017.03.008.

29. de Melo ET, Estrela AB, Santos EC, Machado PR, Farias KJ, Torres TM, et al. Structural characterization of a novel peptide with antimicrobial activity from the venom gland of the scorpion Tityus stigmurus: Stigmurin. Peptides. 2015; 68: 3-10. doi: 10.1016/j.peptides.2015.03.003.

30. Ponnappan N, Chugh A. Cell-penetrating and cargodelivery ability of a spider toxin-derived peptide in mammalian cells. Eur J Pharm Biopharm. 2017;114:145153. doi: 10.1016/j.ejpb.2017.01.012.

31. Lian W, Lian H, Li Q, An H, Liu S. The venom of spider Haplopelma hainanum suppresses proliferation and induces apoptosis in hepatic cancer cells by caspase activation in vitro. J Ethnopharmacol. 2018; 225: 169177. doi: 10.1016/j.jep.2018.06.022.

32. Benli M, Yigit N. Antibacterial activity of venom from funnel web spider Agelena labyrinthica (Araneae: Agelenidae). J Venom Anim Toxins incl Trop Dis. 2008; 14(4): 641-50.

33. Ghasemi-Dizgah A, Amirmozafari N. Evaluation of antibacterial effect of Tarantula cubensisvenome (Theranekron). Int J Bioplogy Pharm Appl Sci. 2015; 4: 5980-9.

34. Lei Q, Yu H, Peng X, Yan S, Wang J, Yan Y, et al. Isolation and preliminary characterization of proteinaceous toxins with insecticidal and antibacterial activities from black widow spider (L. tredecimguttatus) eggs. Toxins. 2015; 7(3): 886-99. 